\title{
PELATIHAN PENJADWALAN DENGAN MS PROJECT BAGI PENYEDIA JASA KONSTRUKSI DI KOTA PEKANBARU
}

\author{
Gusneli Yanti*1, Zainuri ${ }^{2}$, Shanti Wahyuni Megasari ${ }^{3}$ \\ 1,2,3Program Studi Teknik Sipil, Fakultas Teknik, Universitas Lancang Kuning \\ Jalan Yos Sudarso Km. 8 Rumbai Telp (0761) 52324 Pekanbaru-Riau \\ *E-mail : gusneli@unilak.ac.id
}

\begin{abstract}
One determinant of the success of the construction worker is the accuracy of the work scheduling plan. But the limitations of knowledge and skills, the making of scheduling is still carried out manually. Whereas government projects since 2017 have provided requirements that the scheduling must use a program or scheduling application that is intended to be MS Project. If the contractor does not meet these requirements, the biggest possibility is that they will not be able to win the project. The main problem of partners is the lack of knowledge and skills in making scheduling using the MS Project application, so the solution offered to solve the problem is to carry out the Scheduling Training using the MS Project Application. The partners involved are CV. Summit Mas and CV. Fiwi Teknik. The implementation methods used in community service activities are lectures, practices, and discussions. From the training results obtained by the participants' knowledge before the training (pre-test) got an average score of 62,85 in the sufficient category, the assessment of the average practice of Ms. Project's use of training participants obtained an average value of 92,25 in the excellent category, the final assessment (post-test) is 88,46 in the very good category, this proves that Job Scheduling Training with Ms. Project Applications For Construction Service Providers in the City of Pekanbaru is very useful and able to increase knowledge in completing Application-based Ms. Project training participants.
\end{abstract}

Keywords - Training, Scheduling, MS Project

Abstrak
Salah satu penentu keberhasilan suatu pekerjaan konstruksi adalah keakuratan perencanaan penjadwalan pekerjaan. Namun keterbatasan pengetahuan dan keterampilan, maka pembuatan penjadwalan masih dilaksanakan secara manual. Sedangkan proyek-proyek pemerintah sejak tahun 2017, telah memberikan persyaratan bahwa penjadwalan yang dilakukan harus menggunakan program atau aplikasi penjadwalan yang diantaranya adalah MS Project. Apabila kontraktor tidak memenuhi persyaratan tersebut, maka kemungkinan terbesar mereka tidak akan bisa memenangkan proyek tersebut. Permasalahan utama mitra adalah kurangnya pengetahuan dan keterampilan dalam membuat penjadwalan dengan menggunakan aplikasi MS Project, sehingga solusi yang ditawarkan untuk menyelesaikan permasalahan adalah melaksanakan Pelatihan Penjadwalan dengan Menggunakan Aplikasi MS Project. Mitra yang dilibatkan yaitu CV. Sumpit Mas dan CV. Fiwi Teknik. Metode pelaksanaan yang digunakan dalam kegiatan pengabdian kepada masyarakat ini adalah ceramah, praktek dan diskusi. Dari hasil pelatihan diperoleh Pengetahuan peserta sebelum dilakukan pelatihan (pre-test) mendapatkan nilai rata-rata 62,85 dalam kategori cukup, penilaian rata-rata praktek penggunaan Ms Project terhadap peserta pelatihan didapat nilai rata-rata adalah 92,25 dalam kategori sangat baik, penilaian akhir (post-test) adalah 88,46 dalam kategori sangat baik, ini membuktikan bahwa Pelatihan Penjadwalan Pekerjaan dengan Aplikasi Ms Project Bagi Penyedia Jasa Konstruksi di Kota Pekanbaru sangat bermanfaat dan mampu meningkatkan pengetahuan di dalam menyelesaikan penjadwalan berbasis Aplikasi Ms Project peserta pelatihan.

Kata kunci-Pelatihan, Penjadwalan, MS Project 


\section{PENDAHULUAN}

Salah satu elemen terpenting dalam perencanaan suatu pekerjaan konstruksi adalah tahapan perencanaan penjadwalan. Penjadwalan atau scheduling adalah pengalokasian waktu yang tersedia untuk melaksanakan masing-masing pekerjaan dalam rangka menyelesaikan suatu proyek hingga tercapai hasil optimal dengan mempertimbangkan keterbatasan-keterbatasan yang ada [1]. Kota Pekanbaru memiliki banyak perusahaan penyedia jasa konstruksi baik perusahaan kontraktor maupun konsultan. Salah satu perusahaan kontraktor adalah CV. Sumpit Mas dan CV. Fiwi Teknik yang telah banyak melaksanakan pekerjaan konstruksi baik di dalam maupun di luar Kota Pekanbaru, bekerjasama dengan perusahaan swasta maupun dengan proyek-proyek pemerintah. Kedua perusahaan tersebut masih menggunakan perencanaan secara manual, sedangkan sejak tahun 2017 proyek-proyek pemerintah telah memberikan persyaratan bahwa penjadwalan yang dilakukan harus menggunakan program atau aplikasi penjadwalan yang salah satunya adalah MS Project. Apabila kontraktor tidak memenuhi persyaratan tersebut, maka kemungkinan terbesar mereka tidak akan bisa memenangkan proyek tersebut. Penjadwalan harus dibuat secara detail dari awal dimulai pekerjaan hingga penyelesaian akhir pekerjaan. Penjadwalan yang tidak tepat dapat mengakibatkan pekerjaan terlambat, terhambat oleh faktor-faktor tertentu hingga pekerjaan yang tidak dapat selesai tepat pada waktunya.

Permasalahan mitra melaksanakan penjadwalan secara manual, mitra kurang memiliki pengetahuan dan keterampilan tentang penjadwalan pada proyek kontruksi berbasis aplikasi MS Project, dan ketergantungan mitra akan pihak lain untuk membuat penjadwalan pada proyek kontruksi berbasis aplikasi. Pada tahun 2018 yang lalu, perusahaan CV. Sumpit Mas dan CV. Fiwi Teknik meminta kepada Program Studi Teknik Sipil Universitas Lancang Kuning untuk dapat memberikan pelatihan penjadwalan dengan menggunakan aplikasi MS Project, namun dikarenakan keterbatasan waktu dan biaya maka Program Studi Teknik Sipil Universitas Lancang Kuning hanya dapat melaksanakan pelatihan kepada CV. Sumpit Mas dan hanya terbatas pada Pelatihan Pembuatan Bachart dengan Menggunakan Aplikasi MS Project.

Setelah pelaksanaan Pelatihan Pembuatan Bachart dengan Menggunakan Aplikasi MS Project tersebut, karyawan CV Sumpit Mas mendapatkan banyak tambahan pengetahuan dan keterampilan namun hanya dalam pembuatan Bachart dengan MS Project. Maka perusahaan CV Sumpit Mas meminta kembali untuk diberikan pelatihan secara menyeluruh dalam pembuatan penjadwalan pekerjaan konstruksi dengan menggunakan aplikasi MS Project. Sehingga Program Studi Teknik Sipil kembali bekerjasama dengan CV Sumpit Mas serta mengikutsertakan CV Fiwi Teknik untuk memberikan pembinaan kepada para karyawannya dalam Pelatihan Penjadwalan Pekerjaan Konstruksi dengan Menggunakan Aplikasi MS Project.

Mengacu artikel yang ada [2] melakukan batasan penilaian melalui angka terhadap peningkatan peserta pelatihan. Penelitian lainnya mengenai peenjadwalan dengan MS Project [3]

\section{METODE}

Kegiatan Pengabdian Kepada Masyarakat ini melibatkan 2 (dua) mitra yaitu CV. Sumpit Mas yang beralamat di Jalan Rajawali Sakti Gang Flamboyan No. 1 Kelurahan Simpang Baru Kecamatan Tampan Kota Pekanbaru dan CV. Fiwi Teknik yang beralamat di Jalan Musyawarat Gang Abdul Wahab No. 12 Kelurahan Labuh Baru Barat. Metode pelaksanaan kegiatan Pengabdian Kepada Masyarakat adalah metode ceramah, praktek dan diskusi.

\subsection{Tahapan Pelaksanaan}

Pada pelatihan ini dilaksanakan selama 2 hari yang dibagi atas 5 (lima) sesi. Tahapan pelaksanaan pelatihan yang dilaksanakan pada hari pertama, diberikan materi berupa pengenalan Ms Project, Membuat Proyek baru, Menciptakan Task dan Penjadwalan. Pada Sesi pertama kegiatan dimulai dengan menyebarkan ujian pendahuluan (pre-test) sebagai indikator pengukur pengetahuan peserta terhadap topik yang akan disampaikan sebelum dilakukan pelatihan. Sesi kedua diberikan pengetahuan tentang pengenalan Ms Project, membuat proyek baru [4], dilanjutkan dengan sesi ketiga diberikan teori tentang Creating Task Sesi keempat diberikan 
pengetahuan Penjadwalan, pada sesi kelima masih melanjutkan tentang penjadwalan dan diskusi tentang topik yang disampaikan.

Pada hari kedua, diberikan materi berupa Sumberdaya [5], yang dibagi menjadi beberapa sesi dimulai dengan sesi pertama diberikan pengetahuan penggunaan Resourcing a Project dilanjutkan sesi kedua diberikan pengetahuan Resoucing Concept/ komsep sumber daya dan Assigning Resources (penugasan sumberdaya) dengan aplikasi MS Project, dilanjutkan sesi ketiga diberikan contoh kasus dengan aplikasi MS Project. Sesi keempat menyelesaikan studi kasus dengan aplikasi MS Project dan sesi terakhir ditutup dengan (post test) terhadap kemampuan peserta pelatihan untuk mengetahui sejauh mana materi pelatihan dapat diserap oleh peserta pelatihan. Evaluasi diberikan dalam bentuk soal-soal yang harus dijawab dengan benar oleh peserta pelatihan dalam bentuk ujian tertulis.

\subsection{Sistem Evaluasi}

Penilaian dilakukan terhadap jawaban peserta pelatihan dalam menjawab lembar pertanyaan yang diberikan dan keaktifan peserta selama pelaksanaan pelatihan. Evaluasi yang dilaksanakan meliputi :

a. Penilaian pendahuluan (pre-test), yang dilaksanakan sebagai indikator pengukur pengetahuan peserta terhadap topik yang akan disampaikan sebelum dilakukan pelatihan

b. Penilaian studi kasus praktek menggunakan aplikasi MS Project

c. Penilaian akhir (post-test), yang dilaksanakan sebagai indikator terhadap peningkatan pengetahuan peserta terhadap topik yang akan disampaikan setelah dilakukan pelatihan

Penilaian tersebut digunakan untuk membandingkan pengetahuan peserta sebelum dan sesudah pelatihan yang diberikan. Penentuan kategori penilaian menurut pada batasan penilaian sebagai berikut :
1. $<40$
: sangat kurang
2. $\leq 40-<55 \quad$ : kurang
3. $\leq 55-<70 \quad$ : cukup
4. $\leq 70-<85 \quad$ : baik
5. $\leq 85-100 \quad$ : sangat baik

Bila terjadi peningkatan yang cukup signifikan dapat dikatakan pelatihan yang diberikan memberikan hasil positif sesuai yang diharapkan. Dengan kata lain bukan besarnya nilai yang diperhitungkan tapi peningkatan nilai yang menjadi perhatian utama kegiatan pengabdian kepada masyarakat.

\section{HASIL DAN PEMBAHASAN}

Pelatihan Pengabdian Kepada Masyarakat ini melibatkan 2 (dua) mitra yaitu CV. Sumpit Mas yang beralamat di Jalan Rajawali Sakti Gang Flamboyan No. 1 Kelurahan Simpang Baru Kecamatan Tampan Kota Pekanbaru dan CV. Fiwi Teknik yang beralamat di Jalan Musyawarat Gang Abdul Wahab No. 12 Kelurahan Labuh Baru Barat.Tempat pelatihan dilaksanakan di Program Studi Teknik Sipil Universitas Lancang Kuning Jalan Yos Sudarso Km 8 Rumbai Pekanbaru. Waktu pelaksanaan pelatihan dilaksanakan selama 2 (dua) dimulai dari pukul 09.00 sampai 15.00 WIB Peserta pelatihan masing-masing mitra mengirimkan 3 (tiga) orang karyawan, sehingga total peserta pelatihan sebanyak 6 (enam) orang.

\subsection{Pelatihan}

Pelatihan dibuka ketua tim pengabdian dan memperkenalkan anggota tim Pengabdian serta menyampaikan maksud dan tujuan serta manfaat bagi peserta tentang Penjadwalan dengan MS Project. Sesi Pertama hari pertama sebelum dilaksanakan pelatihan, terlebih dahulu disebarkan lembar ujian pendahuluan (pre-test) sebagai indikator pengukur pemahaman dan pengetahuan peserta terhadap topik yang akan disampaikan sebelum dilakukan pelatihan. Penilaian pendahuluan diberikan dalam bentuk soal multi choice yang harus dijawab oleh peserta pelatihan. Soal yang dibagikan berisi pengetahuan dasar peserta tentang materi pelatihan. Setiap peserta pelatihan harus menjawab setiap pertanyaan yang tertera secara perorangan tidak boleh bekerja sama. Sesi kedua, 
diberikan pengetahuan tentang pengenalan Ms Project, dan membuat proyek baru. Pada tahapan ini instruktur memberikan penjelasan mengenai Manajemen proyek secara umum kemudian dilanjutkan dengan pengenalan MS Project, perkembangan versi Ms project dan perbedaan mendasar dari masing-masing versi secara umum. Inteface Ms project versi 2016 dan versi 2007, pada awal pelatihan ini juga diberikan penjelasa sekilas tentang Ms Project secara umum mulai dari cara memulai proyek, mengelola Ms Project, navigasi Ms Project, setting Ms Project, View dan bentuk report Ms Project, kemudian dilanjutkan dengan materi membuat proyek baru (creating a new project), apa langkah dalam membuat sebuah proyek, bagaimana memahami proyek, melihat opsi kalender dan mengubah opsi kalender, bagaimana cara membuat hari libur nasional dalam kalender menggunakan program MS Project dan mengatur project information (gambar 1). Sesi ketiga, diberikan teori tentang Creating Task yaitu dengan memahami task, mengetahui icon penjadwalan, cara memasukan task, meninjau proyek, membuat ringkasan Task, bekerja dalam sheet view, memeriksa informasi tugas, dusari tugas dan memeriksa kemajuan (check Progress).

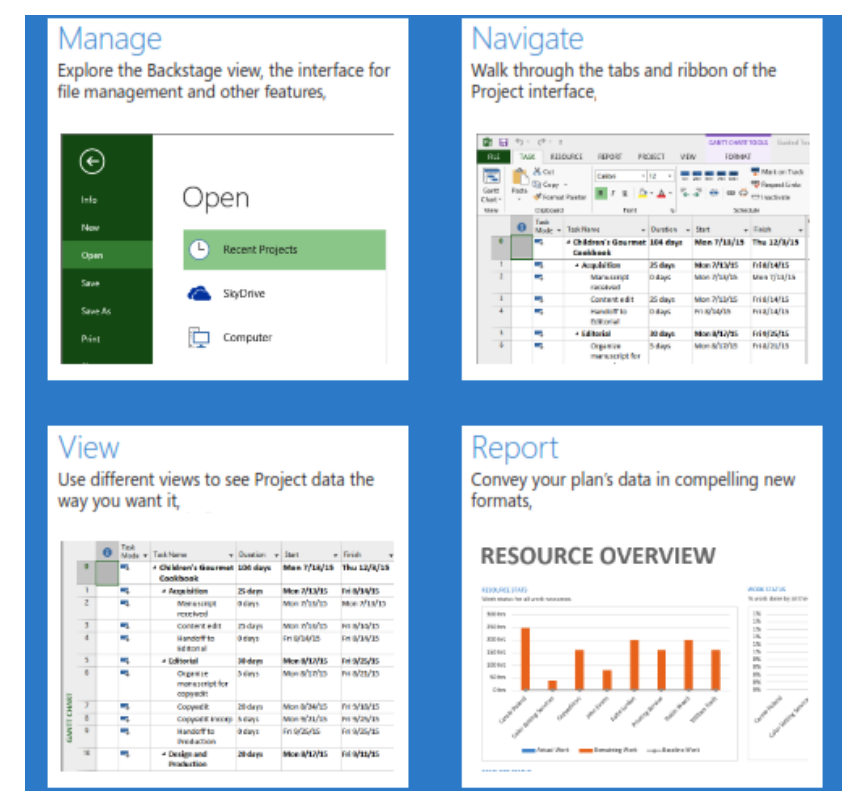

Gambar 1 Sekilas tentang MS Project

Sesi keempat, diberikan pengetahuan tentang penjadwalan proyek yang membahas tentang memahami hubungan ketergantungan tugas, mengubah Jadwal menggunakan hubungan ketergantungan, penjadwalan otomatis dan pada dengan materi critical Path and Project Slack, dan Lead time(Lag), pada pelatihan ini selalu dilakukan diskusi dan pemecahan contoh kasus menggunakan MS Project, selama pelaksanaan praktek di ruangan peserta penggunakan laptop untuk aplikasi MS Project. Selama pelaksanaan pelatihan peserta terlihat semangat, keingintahuan dan keaktifan dari para peserta dalam mengikuti pelatihan (gambar 2)
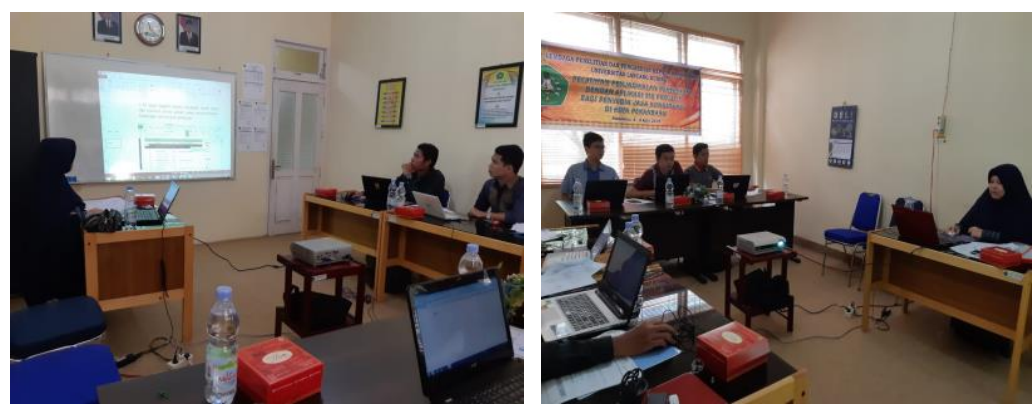

Gambar 2 Instruktur memberikan materi pelatihan dan diskusi dengan Peserta 
Pelaksanaan pelatihan di hari kedua, diberikan materi berupa Sumberdaya sesi pertama yang memberikan pengetahuan Resourcing a Project dengan materi yang dibahas mengenai Sumber daya, jenis sumber daya, ketersediaan sumberdaya dan menetapkan kalender sumber daya dengan aplikasi MS Project, dilanjutkan Sesi kedua diberikan pengetahuan Resoucing Concept/ konsep sumber daya dan Assigning Resources (penugasan sumberdaya) dengan aplikasi MS Project, masih dengan materi sumber daya diantaranya jenis task dan work effort, menambahkan sumberdaya tambahan, sumberdaya part time, penggunaan sumberdaya, jam kerja misalnya untuk jam kerja tertentu. (gambar 3)

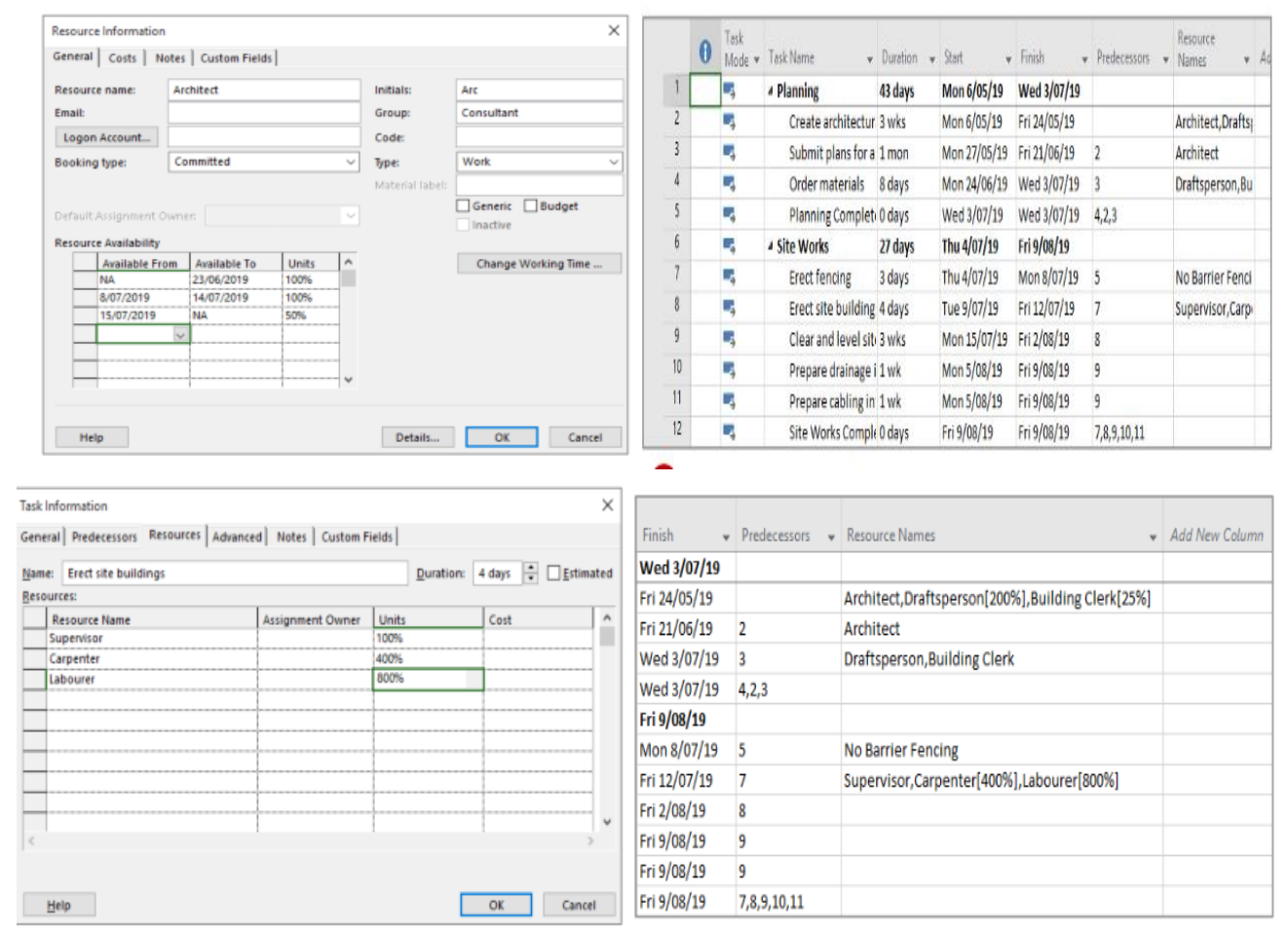

Gambar 3. Tampilan Resource dalam Ms Project

Sesi ketiga diberikan contoh kasus dengan aplikasi MS Project. Pada sesi keempat menyelesaikan studi kasus dengan menggunakan MS Project, pada sesi ini peserta sangat antusias dan serius dalam memecahkan kasus yang diberikan seperti terlihat pada gambar 4.
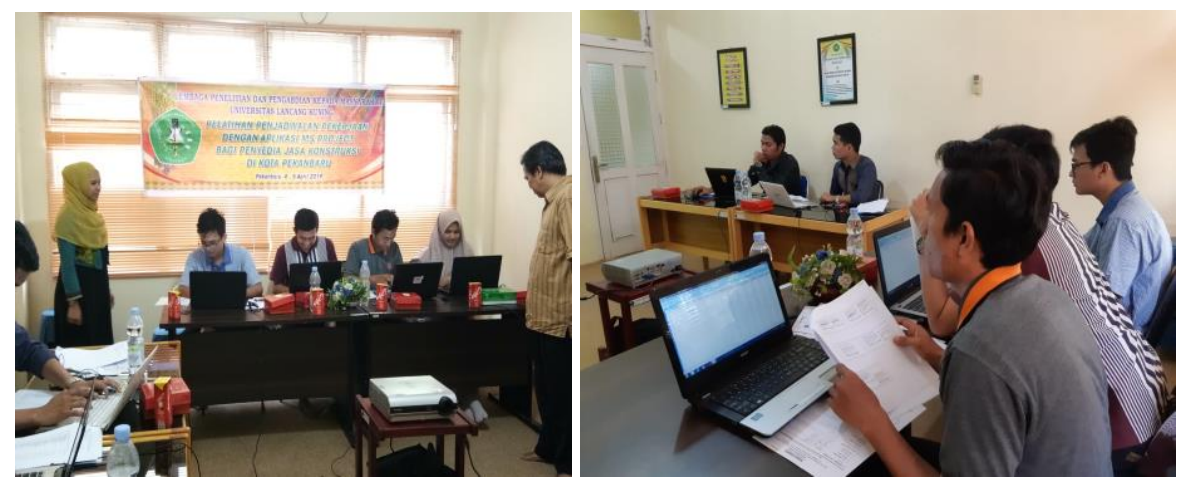

Gambar 4 Suasana Pada saat Penyelesaian Studi Kasus

Sesi kelima, merupakan sesi terakhir ditutup dengan (post test) terhadap kemampuan peserta pelatihan untuk mengetahui sejauh mana materi pelatihan dapat diserap oleh peserta pelatihan. Evaluasi diberikan dalam bentuk soal-soal yang harus dijawab dengan benar oleh peserta pelatihan dalam bentuk ujian tertulis (post-test). Acara pelatihan ditutup dengan foto bersama instruktur dan peserta pelatihan (gambar 3) 

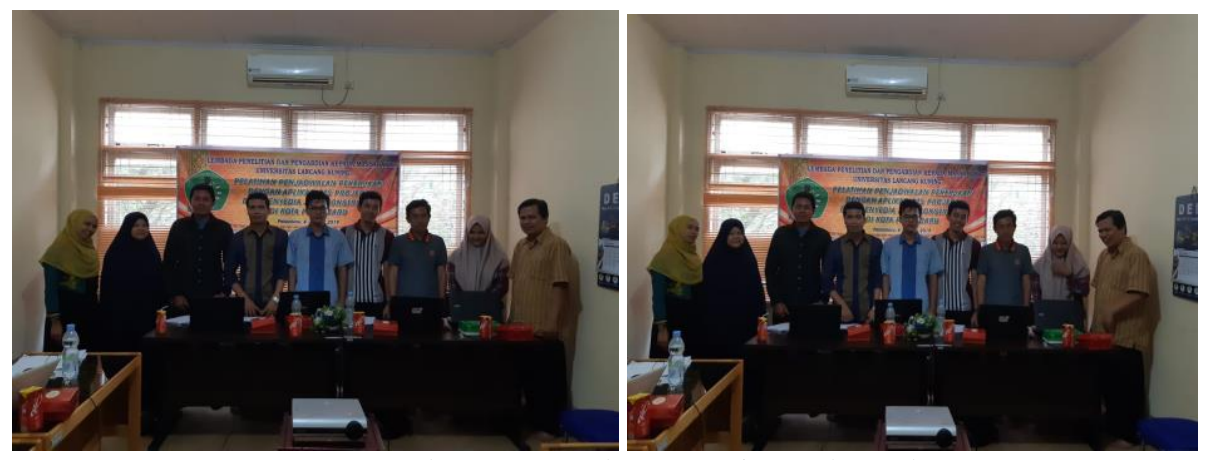

Gambar 5 Foto bersama instruktur dan peserta

\subsection{Tahapan Evaluasi Pelatihan}

Evaluasi yang dilakukan pada pelatihan pembuatan barchart dengan MS Project ini sebanyak 3 (tiga) tahapan, yaitu :

a. Penilaian pendahuluan (pre-test)

Penilaian pendahuluan (Pre-test) yang dilaksanakan sebagai indikator pengukur pengetahuan peserta terhadap topik yang akan disampaikan sebelum dilakukan pelatihan. Setelah dilakukan penilaian pendahuluan ( pre-test) kepada peserta pelatihan, hasil ujian dapat dilihat dalam table 1

\begin{tabular}{clcc}
\multicolumn{4}{c}{ Tabel 1 . Hasil penilaian pendahuluan (pre-test) peserta pelatihan } \\
\hline No. & \multicolumn{1}{c}{ Nama } & Mitra & Nilai \\
\hline 1 & Rafidianto Wibisono & CV. Fiwi Teknik & 68,75 \\
\hline 2 & Deni Lisman & CV. Fiwi Teknik & 66,67 \\
\hline 3 & Bima Adi Nugraha & CV. Fiwi Teknik & 56,25 \\
\hline 4 & Syafrudin & CV. Sumpit Mas & 64,58 \\
\hline 5 & Zulvendra Dinata & CV. Sumpit Mas & 56,25 \\
\hline 6 & Miskar Diana & CV. Sumpit Mas & 64,58 \\
\hline \multicolumn{4}{c}{ Rata-rata Pre Test } \\
\hline
\end{tabular}

Dari hasil penilaian pendahuluan (pre-test) terhadap peserta pelatihan didapat nilai rata-rata adalah 62,85 . Dengan nilai rata-rata tersebut diketahui bahwa pengetahuan peserta pelatihan dalam kategori cukup $(\leq 55-<70)$. Dimana persentase hasil perolehan nilai masing-masing peserta pelatihan $100 \%$ peserta pelatihan pada kategori cukup. Dari 6 (enam) orang peserta pelatihan yang mengikuti penilaian pendahuluan (pre-test). Ketidakadaan nilai sangat kurang menunjukkan bahwa peserta yang mengikuti pelatihan ini memang merupakan praktisi di bidang ilmu teknik sipil yang secara tidak langsung sudah memahami hal-hal yang berkaitan dengan bidang teknik sipil.

b. Penilaian terhadap penggunakan MS Project untuk studi kasus penjadwalan.

Pada tahapan ini instruktur memberikan penilaian mengenai ketepatan dalam settingan waktu, memasukkan data, organisasi data, Gantchart, dan Network. Penilaian diberikan secara individual terhadap masing-masing peserta pelatihan. Aspek dinilai pada Studi Kasus Penjadwalan adalah :

1). Ketepatan Setting waktu, memasukkan data, bobot nilai 35

2). Organisasi data dengan MS Project, bobot nilai 35

3). Membuat Gantchart, lintasan kritis dan Network dengan MS Project, bobot nilai 30

Setelah dilakukan penilaian terhadap penggunakan MS Project untuk studi kasus penjadwalan peserta pelatihan, hasil penilaian dapat dilihat dalam tabel 2

Tabel 2. Hasil penilaian Studi kasus peserta pelatihan 


\begin{tabular}{lllc}
\hline No. & \multicolumn{1}{c}{ Nama } & \multicolumn{1}{c}{ Mitra } & $\begin{array}{c}\text { Penilaian Studi } \\
\text { Kasus }\end{array}$ \\
\hline 1 & Rafidianto Wibisono & CV. Fiwi Teknik & 98 \\
\hline 2 & Deni Lisman & CV. Fiwi Teknik & 90 \\
\hline 3 & Bima Adi Nugraha & CV. Fiwi Teknik & 87,5 \\
\hline 4 & Syafrudin & CV. Sumpit Mas & 98 \\
\hline 5 & Zulvendra Dinata & CV. Sumpit Mas & 85 \\
\hline 6 & Miskar Diana & CV. Sumpit Mas & 95 \\
\hline \multicolumn{2}{l}{ Rata-rata Penilaian Studi Kasus } & $\mathbf{9 2 , 2 5}$ \\
\hline
\end{tabular}

Dari hasil penilaian Penyelesaian Studi Kasus terhadap peserta pelatihan didapat nilai rata-rata adalah 92,25. Dengan nilai rata-rata tersebut diketahui bahwa pemahaman peserta dalam menyelesaikan kasus yang diberikan dalam kategori sangat baik $(\geq 85-100)$. Dimana persentase hasil perolehan nilai $100 \%$ peserta kategori sangat baik penilaian praktek penggunaan MS Project. Selama pelaksanaan pelatihan dapat dilihat antusiasme peserta, dalam menggali pengetahuan tentang penjadwalan berbasis aplikasi Ms Project. Selama sesi diskusi dan tanya jawab, peserta banyak memberikan pertanyaan kepada instruktur terkait penjadwalan berbasis aplikasi Ms Project

c. Penilaian akhir (post-test)

Pada sesi terakhir dilaksanakan penilaian akhir (post-test), yang dilaksanakan sebagai indikator terhadap peningkatan pengetahuan peserta terhadap topik yang akan disampaikan setelah dilakukan pelatihan. Setelah dilakukan penilaian akhir kepada peserta pelatihan, hasil ujian dapat dilihat dalam tabel 3.

Tabel 3. Hasil penilaian akhir (post-test) peserta pelatihan

\begin{tabular}{lllc}
\hline No. & \multicolumn{1}{c}{ Nama } & \multicolumn{1}{c}{ Mitra } & Post-Test \\
\hline 1 & Rafidianto Wibisono & CV. Fiwi Teknik & 92,31 \\
\hline 2 & Deni Lisman & CV. Fiwi Teknik & 90,38 \\
\hline 3 & Bima Adi Nugraha & CV. Fiwi Teknik & 82,69 \\
\hline 4 & Syafrudin & CV. Sumpit Mas & 88 \\
\hline 5 & Zulvendra Dinata & CV. Sumpit Mas & 84,62 \\
\hline 6 & Miskar Diana & CV. Sumpit Mas & 95,31 \\
\hline \multicolumn{4}{c}{ Rata-rata Post Test } \\
\hline
\end{tabular}

Setelah dilakukan penilaian akhir (post-test) terhadap peserta pelatihan diperoleh nilai ratarata adalah 88,46 . Dengan nilai rata-rata post-test dapat dikatakan bahwa pemahaman peserta pelatihan terhadap materi yang diberikan mengalami peningkatan dari kategori pre -test adalah cukup menjadi kategori sangat baik ( $\geq 85$ - 100). Dimana persentase hasil perolehan nilai masingmasing peserta pelatihan adalah sebagai berikut :

1. Dua orang $(33,33 \%)$ kategori baik untuk penilaian Posttest pada pelatihan penjadwalan pekerjaan dengan aplikasi ms project bagi penyedia jasa konstruksi di kota Pekanbaru.

2. Empat orang $(66,67 \%)$ kategori sangat untuk penilaian Posttest pada pelatihan penjadwalan pekerjaan dengan aplikasi ms project bagi penyedia jasa konstruksi di kota Pekanbaru.

Rekapitulasi penilaian yang diperoleh peserta pelatihan dari ketiga tahapan evaluasi dapat dilihat dalam gambar 6 


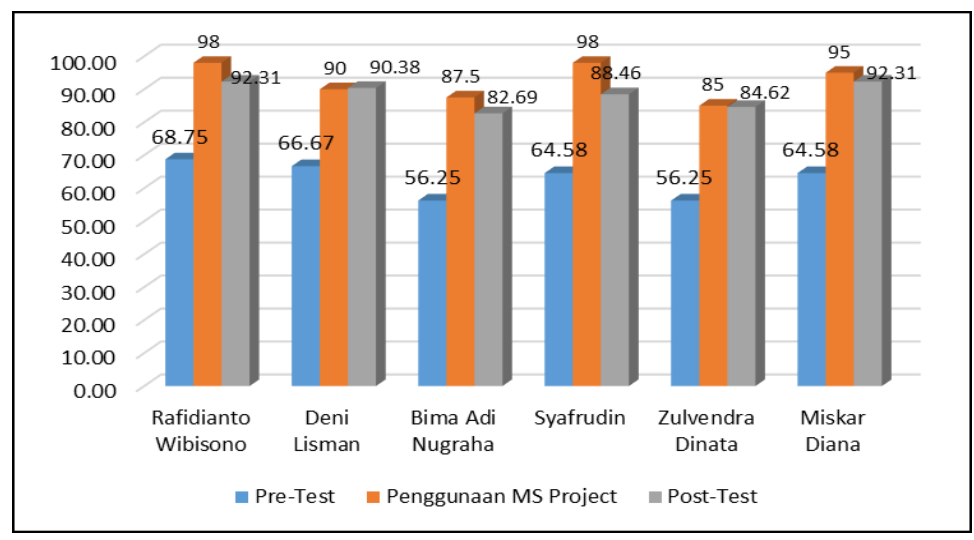

Gambar 7. Rekapitulasi Hasil Penilaian Peserta Pelatihan

Rata- rata Hasil Peserta Pelatihan Penjadwalan Pekerjaan dengan Aplikasi Ms Project bagi Penyedia Jasa Konstruksi di Kota Pekanbaru dapat dilihat pada table 4.

Tabel 4. Rata hasil Penilaian peserta pelatihan

\begin{tabular}{lllc}
\hline No. & \multicolumn{1}{c}{ Nama } & \multicolumn{1}{c}{ Mitra } & Rata-rata \\
\hline 1 & Rafidianto Wibisono & CV. Fiwi Teknik & 86,35 \\
\hline 2 & Deni Lisman & CV. Fiwi Teknik & 82,35 \\
\hline 3 & Bima Adi Nugraha & CV. Fiwi Teknik & 75,48 \\
\hline 4 & Syafrudin & CV. Sumpit Mas & 83,68 \\
\hline 5 & Zulvendra Dinata & CV. Sumpit Mas & 75,26 \\
\hline 6 & Miskar Diana & CV. Sumpit Mas & 83,89 \\
\hline \multicolumn{2}{c}{ Rata-rata Post Test } \\
\hline
\end{tabular}

Berdasarkan penilaian total rata-rata peserta Pelatihan Penjadwalan Pekerjaan dengan Aplikasi Ms Project bagi Penyedia Jasa Konstruksi di Kota Pekanbaru yang diperoleh dari 3 (tiga) tahapan evaluasi yang dilakukan, diperoleh nilai total rerata sebesar 81,19. Dengan nilai total ratarata tersebut, diketahui bahwa dari awal hingga akhir pelaksanaan pelatihan, pengetahuan, pemahaman, keterampilan dalam pembuatan jadwal pekerjaan berbasis aplikasi Ms Project peserta mengalami peningkatan yang sangat signifikan yaitu berada dalam kategori baik $(\leq 70-<85)$. Dimana persentase hasil perolehan100 persen peserta pelatihan kategori baik dalam pengetahuan, pemahaman, keterampilan dalam pembuatan jadwal barchart berbasis aplikasi Ms Project.

Secara keseluruhan persentase pengetahuan peserta mengalami peningkatan yang sangat signifikan hal itu dibuktikan dari gambar 8 diketahui hasil pre test diketahui $100 \%$ dari peserta termasuk dalam kategori cukup, dilihat dari pertanyaan yang ada peserta mempunyai pengetahuan mengenai penjadwalan secara menual namun kurang dalam penggunaan aplikasi Ms Project. Penilaian terhadap penggunaan Ms Project oleh peserta setelah dilakukan pelatihan terlihat peningkatan pengetahuan mengenai aplikasi Ms project untuk penjadwalan dalam kategori sangat baik untuk keseluruhan peserta. Sehingga dapat dikatakan bahwa setelah dilaksanakannya pelatihan, peserta pelatihan memperoleh peningkatan pengetahuan, pemahaman, keterampilan, apabila dibandingkan sebelum mengikuti pelatihan.

Berdasarkan pada hasil penilaian tersebut, membuktikan bahwa pelatihan penjadwalan berbasis Aplikasi Ms Project sangat bermanfaat dan mampu meningkatkan pengetahuan, pemahaman, peserta pelatihan 


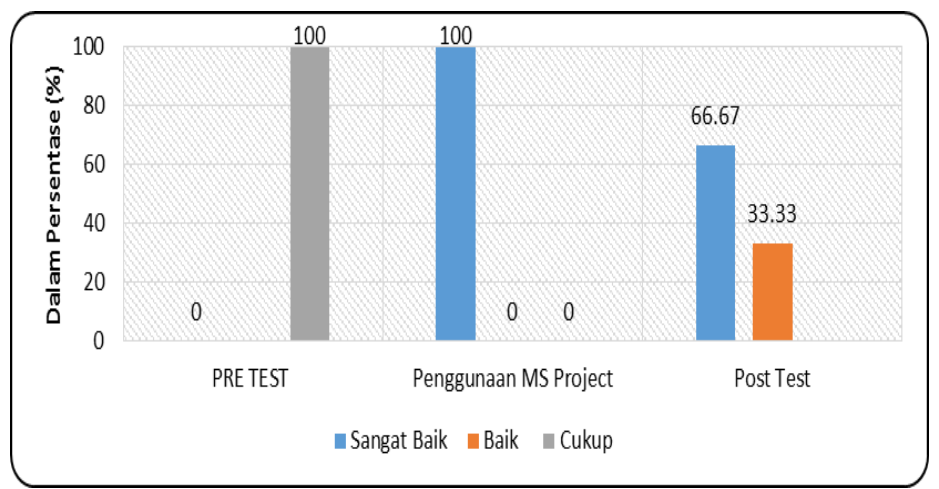

Gambar 8 Kategori Penilaian Hasil Pelatihan

\section{KESIMPULAN}

Penilaian terhadap peserta Pelatihan Penjadwalan Pekerjaan dengan Aplikasi Ms Project bagi Penyedia Jasa Konstruksi di Kota Pekanbaru mulai dari awal sampai akhir pelatihan, diperoleh kesimpulan sebagai berikut:

1. Penilaian pendahuluan (pre-test) terhadap peserta pelatihan didapat nilai rata-rata adalah 62,85 dalam kategori cukup dan Penilaian akhir (post-test) diperoleh nilai rata-rata adalah 88,46 dalam kategori sangat baik, ini membuktikan bahwa Pelatihan Penjadwalan Pekerjaan dengan Aplikasi Ms Project bagi Penyedia Jasa Konstruksi di Kota Pekanbaru mampu meningkatkan pengetahuan

2. Penilaian terhadap Penyelesaian Studi Kasus peserta pelatihan didapat nilai rata-rata adalah 92,25 dalam kategori sangat baik mengenai pengetahuan, pemahaman, dan keterampilan menggunakan Aplikasi Ms Project.

\section{SARAN}

Mengingat pentingnya Pelatihan Penjadwalan Pekerjaan dengan Aplikasi Ms Project bagi Penyedia Jasa Konstruksi di Kota Pekanbaru, ada beberapa saran yang ingin disampaikan. Saransaran tersebut adalah sebagai berikut :

1. Dimasa yang akan datang sebaiknya kegiatan pelatihan dilaksanakan dengan penambahan sumber daya, baik itu tenaga kerja, alat/material sehingga lebih bervariatif dan mendapatkan pengetahuan yang lebih lengkap

2. Sebaiknya kegiatan pelatihan dilanjutkan tidak hanya penjadwalan namun juga pengendalian proyek Dimasa yang akan datang

\section{UCAPAN TERIMA KASIH}

Penulis mengucapkan terima kasih kepada Lembaga Penetian dan Pengabdian Masyarakat, Universitas Lancang Kuning yang telah memberi dukungan financial terhadap pengabdian ini.

\section{DAFTAR PUSTAKA}

[1] Husen, A. 2011, Manajemen Proyek, Andi Ofset, Yogyakarta.

[2] Yanti, G., Zainuri, Z., dan Megasar, S.W., 2017, Analisis Pengaruh Pelatihan Teknologi Penyondiran Pada Usaha Mikro Konstruksi di Kota Pekanbaru, Siklus : Jurnal Teknik Sipil, Vol 3 No 1, hal 39-48.

[3] Wijaya, D,W., Marsiano, F., dan Limanto, S., 2013, Studi Kasus Penjadwalan Proyek Pada Proyek Rumah Toko X Menggunakan Microsoft Project 2010, Jurnal Dimensi Pratama Teknik Sipil, Vol 2 No 1, hal 1-8

[4] Emanuel, A,W,R., Toba, H., dan Djajalaksa, Y, M., 2009, Panduan Lengkap Mengelola Proyek dengan Microsoft Project Profesional 2007, Andi Ofset, Yogyakarta. 
[5] Trihendradi, C. 2011, Microsoft Project 2010 Pendekatan Siklus Proyek Langkah Cerdas Merencanakan dan Mengelola Proyek, Andi Ofset, Yogyakarta..

[6] Kerzner, H. , 2003, Project Manajemen, John Wiley \& Sons, Inc., New Jersey

[7] Rani, H. A. , 2016, Manajemen Proyek Konstruksi, Deepublish, Yogyakarta

[8] Widiasanti, I., \& Lenggogeni., 2013, Manajemen Konstruksi, PT. Remaja Rosdakarya, Jakarta 